\title{
The empirical analysis of production-based entrepreneurship training model, readiness and locus of control towards student's entrepreneurship self efficacy
}

\author{
Ganefri $^{1 *}$, Hendra Hidayat ${ }^{1}$, Asmar Yulastri ${ }^{1}$, Surfa Yondri ${ }^{2}$ \\ ${ }^{1}$ Universitas Negeri Padang, Indonesia \\ ${ }^{2}$ Electrical Engineering Department, Politeknik Negeri Padang, Indonesia \\ *Corresponding author, e-mail: ganefri@unp.ac.id
}

\begin{abstract}
This research was conducted because the students' self-efficacy in entrepreneurship is still low. Production-based entrepreneurship training model, learning readiness is assumed to be a factor that affects student entrepreneurship self-efficacy. The purpose of this study was to examine the contribution of the production-based entrepreneurship training model, learning readiness, and locus of control to student entrepreneurship self-efficacy. This study uses quantitative methods with multiple regression. The population is all students who take the general course of entrepreneurship in Higher Education as many as 500 people, and a sample of 200 students who are selected using proportional stratified random sampling. The questionnaire stands as an effective data collection method to examine the variables to be measured and the answers expected by the respondents. The questionnaire applied the Likert scale by providing opportunities to answer each item. Data were analyzed using multiple regression. The research findings show that there is a joint contribution of the production-based entrepreneurship training model, learning readiness, and locus of control to the entrepreneurial self-efficacy of students.
\end{abstract}

Keywords: Production, Readiness, Locus of Control, Engineering Education, Self Efficacy.

How to Cite: Ganefri, G., Hidayat, H., Yulastri, A., \& Yondri, S. (2021). The empirical analysis of production-based entrepreneurship training model, readiness and locus of control towards student's entrepreneurship self efficacy. International Journal of Research in Counseling and Education, 5 (1): pp. 56-61, DOI: https://doi.org/10.24036/00434za0002

This is an open access article distributed under the Creative Commons 4.0 Attribution License, which permits unrestricted use, distribution, and reproduction in any medium, provided the original work is properly cited. 02021 by author and Universitas Negeri Padang.

\section{Introduction}

Based on statistical data in February 2018, in Indonesia there were 9.5 percent (688,660 people) of the total unemployed who were university alumni, including graduates of higher education. They have a three-year diploma or a bachelor's degree. Of that number, the highest number of unemployed, 495,143 people, are university graduates with a bachelor's degree. Unemployed educated (both diploma and strata 1) increased compared to 2013 with the percentage of unemployed college graduates of 8.36 percent $(619,288$ people) and in 2012 of 8.79 percent (645,866 people). This data describes the low self-confidence of college graduate students to start entrepreneurship. Some of the causes of this weak condition are due to the lack of entrepreneurial training that has occurred so far, which is still oriented to target values, readiness to learn/readiness, and resignation to future fate (locus of control).

The development of awareness and entrepreneurial motives among students is a fundamental need for Innovation and Entrepreneurship, achieving improvement in the quality of human resources so that later in addition to being born as educated people, they are also independent, tenacious, hard working, never give up, responsible, willing to take risks, economically motivated, value time and take advantage of every opportunity, productive, creative and innovative. The learning model becomes the main part of a learning process so it is very important to do a review in the form of a needs analysis. If you look at the high unemployment rate of graduates of higher education, vocational higher education is no exception, it certainly indicates the weakness of the learning process that occurs. The direction of needs analysis of the entrepreneurship training model allows it to be integrated into entrepreneurship learning in higher education, in teaching and learning 
entrepreneurship so that students can master entrepreneurship material with the concept of learning by doing through a production and technology-based learning approach. Needs analysis is a very important initial stage in seeing the needs of a learning model that will be designed, especially a production learning model (Yulastri, \& Hidayat, 2017).

The production-based entrepreneurship training model is in line with the production-based learning model which provides opportunities for students to develop thinking, and skills as well as collaboration (Wisdom, Nurlaela, \& Ismawati, 2020). In the learning process using this model, students are expected to be active, for example; create important questions related to the product to be made. According to (Ganefri, 2013), "production-based learning models are defined as procedures or steps that need to be taken by educators to facilitate students to actively learn, participate and interact, with a competency orientation to produce products, either goods or services needed. Model Production-based learning is a learning model that provides opportunities for students to develop skills in higher vocational education (Hidayat, 2017a; Hidayat, 2017b; Hidayat, 2018).This ability is in the form of critical thinking skills, and working together (Nickerson, 2007). Perkins \& Smith, 1985), is very relevant to the development of learners about the learning experiences they get (Gijselaers, 1996), In the learning process with this production-based learning model students are asked to actively raise important questions related to the product to be made.

Production-based learning models consist of syntax or steps in the learning process, which according to (Ganefri, 2013; Ganefri et al, 2013; Ganefri, and Hidayat, 2014; 2015; Kusumaningrum et al, 2015) in a learning model based on this syntax product or the sequence of steps of the lesson consists of 9 steps: In the learning process with this production-based learning model, students are asked to actively raise important questions related to the product to be made. Production-based learning models consist of syntax or steps in the learning process, which according to (Ganefri, 2013; Ganefri et al, 2013; Ganefri, and Hidayat, 2014; 2015; Kusumaningrum et al, 2015) in a learning model based on this syntax product or the sequence of steps of the lesson consists of 9 steps: In the learning process with this production-based learning model, students are asked to actively raise important questions related to the product to be made. Production-based learning models consist of syntax or steps in the learning process, which according to (Ganefri, 2013; Ganefri et al, 2013; Ganefri, and Hidayat, 2014; 2015; Kusumaningrum et al, 2015) in a learning model based on this syntax product or the sequence of steps of the lesson consists of 9 steps: 1) Analysis of curriculum and characteristics of learners; 2) Product identification and analysis; 3) Make important questions about the product; 4) Mapping the questions; 5) Analysis of equipment and material requirements of the product to be made; 6) Making a schedule for the manufacture of products; 7) Product manufacturing process; 8) Evaluation regularly; and 9) Making a Business Plan.

\section{Method}

This research uses correlational type quantitative methods (multiple regression). The instrument used is a model scale Likert. The research population in this study was 500 students who took part in Higher Education, a sample of 200 people, with 87 males and 113 females, aged 19-20 years, 35 students from electrical engineering majors, engineering majors there are 53 electronics majors, 45 mechanical majors, and 67 civil engineering majors, and are from the 2019 and 2020 entry years, who were selected using the technique proportional stratified random sampling. Furthermore, data was collected by distributing questionnaires to obtain information about student entrepreneurship self-efficacy, production-based entrepreneurship training models, learning readiness, and locus of control. The questionnaire stands as an effective data collection method to examine the variables to be measured and the answers expected by the respondents (Smith, 2019). The questionnaire applied the Likert scale by providing opportunities to answer each item (Awang et al., 2016). Data collection is carried out in Higher Education with the following procedures: 1) Preparing student entrepreneurship self-efficacy, production-based entrepreneurship training models, learning readiness and locus of control; 2) Provide an explanation of the instrument and how to fill it out; 3) Distribute instruments and invite students to fill them out; 4) Collecting instruments according to the plan. Data were analyzed by descriptive statistics that designed to give you information about the distributions of yours variables (Fisher, $\&$ Marshall, 2009; George, \& Mallery, 2016), multiple simple regression that statistical analysis used to determine the effect of several independent variables on the dependent variable (Chen, \& Chen, 2014; Morrissey, \& Ruxton, 2018). Data analysis is assisted by using the SPSS program.

\section{Results and Discussion}

Before carrying out the data analysis process, it is necessary to test for normality, linearity, and multicollinearity where the results are as follows. 
Table 1. Normality Test

\begin{tabular}{|c|c|c|c|}
\hline Variable & Sig.(p) & Sig. alpha & Information \\
\hline Students Entrepreneurship Self Efficacy (Y) & 0.200 & \multirow{4}{*}{0.05} & Normal \\
\hline Production-Based Entrepreneurship Training Model ( $\left.\mathrm{X}_{1}\right)$ & 0.200 & & Normal \\
\hline Learning readiness $\left(\mathrm{X}_{2}\right)$ & 0.200 & & Normal \\
\hline Locus of Control $\left(\mathrm{X}_{3}\right)$ & 0.200 & & Normal \\
\hline
\end{tabular}

Normality testing is carried out using the method Kolmogorov-Smirnov. If asymp. Sig. or P-value $>$ of 0.05 (significance level), then the four research variables are distributed normally.

Table 2. Linearity Test

\begin{tabular}{ccc}
\hline Variable & Significance Level & Conclusion \\
\hline $\mathrm{X}_{1} \mathrm{Y}$ & 0.009 & Linier \\
$\mathrm{X}_{2} \mathrm{Y}$ & 0.003 & Linier \\
$\mathrm{X}_{3} \mathrm{Y}$ & 0.007 & Linier \\
\hline
\end{tabular}

Based on the Table 2, the results show that the relationship between production-based entrepreneurship training models and student entrepreneurship self-efficacy is linear, the relationship between learning readiness and student entrepreneurship self-efficacy is also linear, and the relationship between locus of control and student entrepreneurship self-efficacy is also linear, the meaning of linear is that there is an effect of several independent variables on the dependent variable.

Table 3. Multicollinearity Test

\begin{tabular}{cccc}
\hline Variable & Tolerance & VIF & Information \\
\hline (Constant) & & & \\
$\mathrm{X}_{1}$ & 0.820 & 1.219 & There is no multicollinearity \\
$\mathrm{X}_{2}$ & 0.820 & 1.219 & \\
$\mathrm{X}_{3}$ & 0.820 & 1.219 & \\
\hline
\end{tabular}

The next test is the multicollinearity test. Based on these results, it can be concluded that there is no multicollinearity between the independent variables. Furthermore, the results of hypothesis testing can be seen in the following table.

Table 4. The test results of X1 X2, and X3 to Y

\begin{tabular}{|c|c|c|c|c|c|c|}
\hline \multicolumn{7}{|c|}{ ANOVA $^{\mathrm{a}}$} \\
\hline Model & & Sum of Squares & Df & Mean Square & $\mathbf{F}$ & Sig. \\
\hline \multirow{3}{*}{1} & Regression & 1345.863 & 3 & 678.562 & 11.514 & $0.000^{\mathrm{a}}$ \\
\hline & Residual & 10565.243 & 197 & 48.567 & & \\
\hline & Total & 11911.106 & 200 & & & \\
\hline \multicolumn{7}{|c|}{$\begin{array}{l}\text { a. Dependent Variable: Y } \\
\text { b. Predictors: (Constant), X3, X2, X1 }\end{array}$} \\
\hline
\end{tabular}

Table 4 shows the effect of the production-based entrepreneurial training model, readiness, and locus of control on student entrepreneurship self-efficacy. From this result the table is statistically significant (Sig = 0.000). The three independent variables significantly contribute to increasing student entrepreneurship selfefficacy.

The results showed that the production-based entrepreneurship training model, learning readiness, and locus of control together contributed significantly to student entrepreneurship self-efficacy. The use of production-based entrepreneurship training models can increase interest in entrepreneurship and can increase student self-efficacy for entrepreneurship (Hikmah, Nurlaela, \& Ismawati, 2020). The results of this study reveal that the production-based entrepreneurship training model, learning readiness and locus of control together can be a factor that have an effect on student self-efficacy in entrepreneurship. The use of the production-based entrepreneurship training model will have an impact on increasing student entrepreneurship self-efficacy (Brüne, \& Lutz, 2020; Wardana, Narmaditya, Wibowo, Mahendra, Harwida, \& 
Rohman, 2020). High confidence in themselves for entrepreneurship in students is predicted by the ability of students to condition themselves to be ready for entrepreneurship. Readiness in the sense of being ready physically, psychologically, and materially experienced by students themselves and being able to respond to all actions in the process of becoming an entrepreneur (Raza, Muffatto, \& Saeed, 2019). Students who have good learning readiness will tend to be trained to do something if they are given exercises about what they have learned. If they are trained to use production-based entrepreneurship training strategies that have been taught, it tends to affect their self-efficacy (Mukesh, Pillai, \& Mamman, 2020). This causes a pattern of formation readiness which is different for each individual. So as readiness in learning is very influential on a person's personal development to mature his willingness to learn so that a person will be easy and ready to accept something that will be learned in the learning itself (Hidayat, Tamin, Herawati, Khairul, \& Syahmaidi, 2019).

Furthermore, the production-based entrepreneurship training model contributes to student entrepreneurship self-efficacy. The activeness of students in conducting training activities in the form of finding problems, analyzing needs, and analyzing learning, is predicted to be able to increase the entrepreneurial self-efficacy of students (Kisubi, Korir, \& Bonuke, 2021). The production-based entrepreneurship training model helps students regulate or monitor cognitive, planned, intentional, goaldirected thinking ideas, and mental processing oriented to the belief that they will succeed in the future (To, Martínez, Orero-Blat, \& Chau, 2020). Students who know themselves well will be able to control themselves well, because knowing themselves will improve their learning outcomes. Student with internal locus of control have characteristics like to work hard, always think effectively and have the perception that if you want to succeed, you have to try (DeAngelis, Escobar, Ruiz, \& Acevedo, 2019). Students who have the belief that they participate in influencing all the results achieved in their lives, of course also have the power to solve learning problems. In contrast to students who tend to external locus of control. When faced with problems, he tends to give up and rely on fate.

The production-based entrepreneurship training model is a procedure that helps students to understand and find problems and find solutions to these problems (Hidayat, \& Yuliana, 2018; Hidayat et al., 2018; Hidayat et al., 2019; Kusumaningrum, \& Hidayat, 2016; Ganefri et al., 2020; Yulastri et al., 2021), especially in learning in engineering and vocational education (Hidayat, Ardi, Yuliana \& Herawati, 2019; Tasrif et al., 2021; Hidayat et al., 2021). Furthermore, the production-based entrepreneurship training model will be more effective if the individual tends to have high readiness and locus of control in being successful in starting a business(Asante, 2003). \& Affum-Osei, 2019; Chernyshenko, Ho, Chan, \& Yu, 2020; Horng, Hsiao, LiuChou, \& Chung, ; 2020; Hidayah, 2020; Fisch, Franken, \& Thurik, 2021).

\section{Conclusion}

Based on the findings and discussion of the research results, it can be concluded that the production-based entrepreneurship training model, learning readiness and locus of control jointly contribute significantly to student entrepreneurship self-efficacy. Production-based entrepreneurship training model, learning readiness and locus of control has a significant impact on student entrepreneurship self-efficacy. That is, the high and low self-efficacy of student entrepreneurship is not only influenced by one variable but is jointly influenced by the production-based entrepreneurship training model, learning readiness and locus of control. Furthermore, the recommendations of this study are based on the results of the research, discussion, and conclusions that have been stated previously, so for lecturers and instructors to be able to apply the production-based entrepreneurship model, because it is a good alternative in developing student entrepreneurial competencies.

\section{Acknowledgment}

Thank you for the support and cooperation of all parties so that the implementation of this simple research can be carried out properly and can complete this paper. Furthermore, the highest gratitude and appreciation to the DRPM/BRIN through funding in 2021. This paper is part and output of research in 2021, with a contract: B/112/E3/RA.00/2021.

\section{References}

Asante, E. A., \& Affum-Osei, E. (2019). Entrepreneurship as a career choice: The impact of locus of control on aspiring entrepreneurs' opportunity recognition. Journal of Business Research, 98, 227-235. https://doi.org/10.1016/j.jbusres.2019.02.006

Awang, Z., Afthanorhan, A., \& Mamat, M. (2016). The Likert scale analysis using parametric based Structural Equation Modeling (SEM). Computational Methods in Social Sciences, 4(1), 13-21. http://cmss.univnt.ro/wp-content/uploads/vol/split/vol_IV_issue_1/CMSS_vol_IV_issue_1_art.002.pdf

Barba-Sánchez, V., \& Atienza-Sahuquillo, C. (2018). Entrepreneurial intention among engineering students: The role of entrepreneurship education. European research on management and business economics, 24(1), 53-61. https://doi.org/10.1016/j.iedeen.2017.04.001 
Brüne, N., \& Lutz, E. (2020). The effect of entrepreneurship education in schools on entrepreneurial outcomes: a systematic review. Management Review Quarterly, 70(2), 275-305. https://doi.org/10.1007/s11301019-00168-3

Chen, K. S., \& Chen, H. T. (2014). Applying Importance-Performance Analysis With Simple Regression Model and Priority Indices to Assess Hotels' Service Performance. Journal of Testing and Evaluation, 42(2), 455466. http://dx.doi.org/10.1520/JTE20130124

Chernyshenko, O. S., Ho, M. H. R., Chan, K. Y., \& Yu, K. Y. T. (2020). Operationalizing developmental readiness via entrepreneurship, leadership, and professionalism career dimensions. In EntrepreneurshipProfessionalism-Leadership (pp. 99-110). Springer, Singapore. https://doi.org/10.1007/978-981-153121-7_6

DeAngelis, R. T., Escobar, I., Ruiz, A. L., \& Acevedo, G. A. (2019). Sleep quality among college students: exploring the role of a divine locus of sleep control. Sleep health, 5(6), 592-597. https://doi.org/10.1016/j.sleh.2019.08.004

Fisch, C., Franken, I. H., \& Thurik, R. (2021). Are behavioral and electrophysiological measures of impulsivity useful for predicting entrepreneurship?. Journal of Business Venturing Insights, 16, e00253. https://doi.org/10.1016/j.jbvi.2021.e00253

Ganefri. (2013). The Development of Production-Based Learning Approach to Entrepreneurial Spirit for Engineering Students. Journal Asian Social. Science; 9(12). https://doi.org/10.5539/ass.v9n12p162

Ganefri., Hidayat, H., Kusumaningrum, I., \& Mardin, A. (2017). Needs Analysis of Entrepreneurships Pedagogy of Technology and Vocational Education with Production Base Learning Approach in Higher Education. International Journal on Advanced Science, Engineering and Information Technology, 7(5), 1701-1707. http://dx.doi.org/10.18517/ijaseit.7.5.1510

Ganefri, G., Hidayat, H., Yulastri, A., \& Ifdil, I. (2020). Need analysis of the production based entrepreneurship training model: learning entrepreneurship in higher education. COUNS-EDU: The International Journal of Counseling and Education, 5(2), 58-63. http://dx.doi.org/10.23916/0020200528530

Hidayah, H. N. (2020). Precondition Model for Field Work Practices Based on Project-Based Learning to Improve Vocational School Stundents' Competence and Readiness in Entrepreneurship, Fashion Design Expertise Program. Journal of Vocational and Career Education, 5(2). https://doi.org/10.15294/jvce.v5i2.29366

Hidayat, H. (2017a). Impact of Learning with the Production-Based Learning Model in Vocational School. International Journal of Research in Engineering and Social Sciences, 7(2), 1-6. http://indusedu.org/pdfs/IJRESS/IJRESS_1057_92032.pdf

Hidayat, H. (2017b). How is the Application and Design of a Product-Based Entrepreneurship Learning Tools in Vocational Higher Education?. Advances in Social Science, Education and Humanities Research, volume 102, 223-228. http://dx.doi.org/10.2991/ictvt-17.2017.38.

Hidayat, H., Herawati, S., Hidayati, A., \& Syahmaidi, E. (2018). Pembelajaran Kewirausahaan Dengan Pendekatan Berbasis Produksi Sebagai Alternatif Mempersiapkan Lulusan Berkualitas Di Pendidikan Tinggi. In $\begin{array}{lllll}\text { Prosiding } & \text { Seminar } & \text { Nasional } & \text { 123-129). }\end{array}$ https://trijurnal.lemlit.trisakti.ac.id/pakar/article/view/2709

Hidayat, H., Herawati, S., Syahmaidi, E., Hidayati, A., \& Ardi, Z. (2018). Designing of technopreneurship scientific learning framework in vocational-based higher education in Indonesia. International Journal of Engineering and Technology(UAE), 74), 123-127. https://doi.org/10.14419/ijet.v7i4.9.20632

Hidayat, H., \& Yuliana. (2018). The Influence of Entrepreneurship Education and Family Background on Students' Entrepreneurial Interest in Nutritious Traditional Food Start Ups in Indonesia. International Journal of Engineering and Technology(UAE), 7(4), 118-122. https://doi.org/10.14419/ijet.v7i4.9.20631

Hidayat, H., Tamin, B. Y., Herawati, S., Khairul, K., \& Syahmaidi, E. (2019). The contribution of technopreneurship scientific learning and learning readiness towards the entrepreneurship learning outcomes in higher vocational education. Jurnal Pendidikan Vokasi, 9(1), 21-32. http://dx.doi.org/10.21831/jpv.v9i1.20466

Hidayat, H., Tamin, B.Y., Herawati, S., Hidayati, A., Muji, A.P. (2019). Implementation of technopreneurship scientific learning for produce electronic product prototypes in engineering education. International Journal of Innovative Technology and Exploring Engineering, 8(11), 2842-2846. http://dx.doi.org/10.35940/ijitee.K2406.0981119

Hidayat, H., Ardi, Z., Yuliana, \& Herawati, S. (2019). Exploration of the need analysis for technopreneurship scientific learning models in higher vocational education. International Journal of Economics and Business Research, 18(3), 356-368. http://dx.doi.org/10.1504/IJEBR.2019.102733

Hidayat, H., Tasrif, E., Jaya, P., Anwar, M., Hadi, A., Budayawan, K., ... \& Asmara, D. (2021). The Empirical Analysis of Industrial Work Challenges in the Industrial Revolution 5.0 Towards a Grade Point Average (GPA) for Electronic Engineering Education Students. International Journal of Online \& Biomedical Engineering, 179). https://doi.org/10.3991/ijoe.v17i09.25679

Hikmah, Y. F., Nurlaela, L., \& Ismawati, R. (2020). Influence of Production Based Training Learning Model on Student Learning Outcomes Reviewed from Entrepreneurial Interests. International Journal for Educational and Vocational Studies, 2(3). https://doi.org/10.29103/ijevs.v2i3.2435 
Horng, J. S., Hsiao, H. L., Liu, C. H., Chou, S. F., \& Chung, Y. C. (2020). Learning innovative entrepreneurship: Developing an influential curriculum for undergraduate hospitality students. Journal of Hospitality, Leisure, Sport \& Tourism Education, 100289. https://doi.org/10.1016/j.jhlste.2020.100289

Kisubi, M., Korir, M. ., \& Bonuke, R. . (2021). Entrepreneurial Education and Self-employment: Does Entrepreneurial Self-efficacy Matter?.SEISENSE Business Review, 1(1), 18-30. https://doi.org/10.33215/sbr.v1i1.498

Kusumaningrum, I., \& Hidayat, H. (2016). Learning Outcomes in Vocational Education: A Business Plan Development by Production-Based Learning Model Approach. International Journal of Environmental and Science Education, 11(18), 11917-11930. https://eric.ed.gov/?id=EJ1122558

Morrissey, M. B., \& Ruxton, G. D. (2018). Multiple regression is not multiple regressions: the meaning of multiple regression and the non-problem of collinearity. Philosophy, Theory, and Practice in Biology, 10(3). https://doi.org/10.3998/ptpbio.16039257.0010.003

Mukesh, H. V., Pillai, K. R., \& Mamman, J. (2020). Action-embedded pedagogy in entrepreneurship education: an experimental enquiry. Studies in Higher Education, 45(8), 1679-1693. https://doi.org/10.1080/03075079.2019.1599848

Nabi, G., Liñán, F., Fayolle, A., Krueger, N., \& Walmsley, A. (2017). The impact of entrepreneurship education in higher education: A systematic review and research agenda. Academy of Management Learning \& Education, 16(2), 277-299. https://doi.org/10.5465/amle.2015.0026

Raza, A., Muffatto, M., \& Saeed, S. (2019). The influence of formal institutions on the relationship between entrepreneurial readiness and entrepreneurial behaviour: A cross-country analysis. Journal of small business and enterprise development. https://doi.org/10.1108/JSBED-01-2018-0014

Smith, T. W. (2019). Cross-Cultural and Cross-National Questionnaire Design and Evaluation (pp. 473-492). In Advances in Questionnaire Design, Development, Evaluation and Testing. https://doi.org/10.1002/9781119263685.ch19

Tasrif, E., Saputra, H. K., Kurniadi, D., Hidayat, H., \& Mubai, A. (2021). Designing Website-Based Scholarship Management Application for Teaching of Analytical Hierarchy Process (AHP) in Decision Support Systems (DSS) Subjects. International Journal of Interactive Mobile Technologies, 1699). https://doi.org/ 10.3991/ijim.v15i09.23513

To, C. K., Martínez, J. M. G., Orero-Blat, M., \& Chau, K. P. (2020). Predicting motivational outcomes in social entrepreneurship: Roles of entrepreneurial self-efficacy and situational fit. Journal of Business Research, 121, 209-222. https://doi.org/10.1016/j.jbusres.2020.08.022

Wardana, L. W., Narmaditya, B. S., Wibowo, A., Mahendra, A. M., Wibowo, N. A., Harwida, G., \& Rohman, A. N. (2020). The impact of entrepreneurship education and students' entrepreneurial mindset: the mediating role of attitude and self-efficacy. Heliyon, 6(9), e04922. https://doi.org/10.1016/j.heliyon.2020.e04922

Yulastri, A., \& Hidayat, H. (2017). Developing an Entrepreneurship Module by Using Product-Based Learning Approach in Vocational Education. International Journal of Environmental and Science Education, 12(5), 1097-1109. https://files.eric.ed.gov/fulltext/EJ1145587.pdf

Yulastri, A., Dewi, M., Hidayat, H., Ardi, Z., Yuliana. (2021). The Validation of Smart Entrepreneur Model (SEM) for Student Using Exploratory Factor Analysis (EFA). International Journal on Advanced Science, $\begin{array}{llll}\text { Engineering and } \quad \text { Information } & \text { Technology, }\end{array}$ http://dx.doi.org/10.18517/ijaseit.11.4.13682 